\title{
Sensitivity of Solar Photovoltaic Panel Efficiency to Weather and Dust over West Africa: Comparative Experimental Study between Niamey (Niger) and Abidjan (Côte d'Ivoire)
}

\author{
Alima Dajuma1 ${ }^{*}$, Saleye Yahaya ${ }^{2}$, Siaka Touré ${ }^{3}$, Arona Diedhiou4, Rabani Adamou1,5, \\ Abdourahamane Konaré6, Mariama Sido², Michel Golba7 \\ ${ }^{1}$ WASCAL MRP Climate Change and Energy, Université Abdou Moumouni, Niamey, Niger \\ ${ }^{2}$ Centre National d'Energie Solaire, CNES, Niamey, Niger \\ ${ }^{3}$ Laboratoire d'Energie Solaire, Université Félix Houphouët Boigny, Abidjan, Côte d'Ivoire \\ ${ }^{4}$ LTHE-IRD, Université Grenoble-Alpes, Grenoble, France \\ ${ }^{5}$ Faculté des Sciences et Techniques, Université Abdou Moumouni, Niamey, Niger \\ ${ }^{6}$ Centre d'Excellence Africain en Changement Climatique, Biodiversité et Agriculture Durable (CCBAD), Université Félix Houphouët \\ Boigny, Abidjan, Côte d'Ivoire \\ ${ }^{7}$ Energy and Semiconductor Research Laboratory, Carl von Ossietzky University Oldenburg, Oldenburg, Germany \\ Email: *alima.dajuma@yahoo.com
}

How to cite this paper: Dajuma, A., Yahaya, S., Touré, S., Diedhiou, A., Adamou, R., Konaré, A., Sido, M. and Golba, M. (2016) Sensitivity of Solar Photovoltaic Panel Efficiency to Weather and Dust over West Africa: Comparative Experimental Study between Niamey (Niger) and Abidjan (Côte d'Ivoire). Computational Water, Energy, and Environmental Engineering, 5, 123 147.

http://dx.doi.org/10.4236/cweee.2016.54012

Received: June 26, 2016

Accepted: October 28, 2016

Published: October 31, 2016

Copyright $\odot 2016$ by authors and Scientific Research Publishing Inc. This work is licensed under the Creative Commons Attribution International License (CC BY 4.0).

http://creativecommons.org/licenses/by/4.0/

\section{Abstract}

Energy demand is increasing while we are facing a depletion of fossils fuels, the main source of energy production in the world. These last years, photovoltaic (PV) system technologies are growing rapidly among alternative sources of energy to contribute to mitigation of climate change. However, PV system efficiency researches operating under West African weather conditions are nascent. The first objective of this study is to investigate the sensitivity of common monocrystalline PV efficiency to local meteorological parameters (temperature, humidity, solar radiation) in two contrasted cities over West Africa: Niamey (Niger) in a Sahelian arid area and Abidjan (Côte d'Ivoire) in atropical humid area. The second objective is to quantify the effect of dust accumulation on PV efficiency in Niamey (Niger). The preliminary results show that PV efficiency is more sensitive to high temperature change especially under Niamey climate conditions (warmer than Abidjan) where high ambient temperatures above $33^{\circ} \mathrm{C}$ lead to an important decrease of PV efficiency. Increase of relative humidity induces a decrease of PV efficiency in both areas (Niamey and Abidjan). A power loss up to $12.46 \%$ is observed in Niamey after 21 days of dust accumulation. 


\section{Keywords}

Solar Energy, PV Efficiency, Temperature, Dust, Humidity, Niamey, Abidjan

\section{Background}

Energy is an important development factor of a country. In recent decades, energy has become a significant issue in the world. Indeed, fossil fuel resources are decreasing while the world energy demand is increasing considerably. Moreover, the consumption of fossils fuels causes air pollution and contributes significantly to greenhouse gases (GHGs) emission and to climate change. An obvious solution to overcome ongoing threat of air pollution and to promote GHGs emission mitigation and sustainable energy production is the use of renewable energy sources such as solar, wind, hydro and geothermal.

Solar energy has the largest potential among all the above renewable energy sources. The yearly average solar power resource on the earth's surface is 36,000 billion Watts $\left(3.6 \times 10^{4} \mathrm{TW}\right)$ when the wind power resource is $72 \mathrm{TW}$, geothermal power resource is 9.7 TW [1]. Today, solar energy is captured through two technologies: pure or hybrid photovoltaic (PV) modules and solar thermal collectors.

This work concerned the pure PV solar energy converters which directly convert solar radiation into electricity. Nowadays, PV technologies are widely used around the world in various forms of application such as solar-generated electricity connected to the grid and off-grid domestic systems which provide electricity for houses in rural areas that are not connected to utility electrical network. It provides electricity for lighting, refrigeration and other low power loads. PV technology has been installed worldwide and it is often the most appropriate technology to meet the energy demands of off-grid communities, typically around 1 to 5 kilowatt peak $\left(\mathrm{kW}_{\mathrm{p}}\right)$ in size. Among other off-grid applications, we have non-domestic systems which are mainly used for health centers, schools, telecommunication, water pumping and navigational aids. We can cite also hybrid systems which combine the advantage of PV and diesel hybrid in mini grids. They allow mitigating fuel price increases, deliver operating cost reductions, and offer higher service-quality than traditional single-source generation systems. Elsewhere, PV systems are easy to install, simple in design and require a little maintenance [2] [3]. However, it remains social, political and economic barriers to the full implementation of PV technologies [4]. Additionally, there is a lack of data on PV system operating under West African weather conditions. African market is furnished with PV modules issued from Europe and Asia. Thus, most PV systems are calibrated under standard test conditions (spectral distribution of air mass 1.5; solar radiation of 1000 $\mathrm{W} / \mathrm{m}^{2}$; wind speed of $1 \mathrm{~m} / \mathrm{s}$ and an ambient temperature of $25^{\circ} \mathrm{C}$ ), which are very different from the natural weather conditions in Africa. Hence, the first objective of this study is to investigate the sensitivity of market monocrystalline PV efficiency to local meteorological conditions (temperature, humidity, solar radiation) in two contrasted 
cities over West Africa (as is shown in Figure 1): Niamey (Niger) in a Sahelian arid area and Abidjan (Côte d'Ivoire) in a tropical humid area. The second objective is related to the evaluation of dust effect on PV efficiency. This work is divided in five sections. In the first one, the energetic and renewable energy situation in Niger and Côte d'Ivoire were presented. The second section is a synthesis of the literature review and theoretical aspects on PV technology. The third section, examined the data and methodology of the experimental design used to conduct this study. Results of the impact of cell temperature, ambient temperature, solar radiation and dust accumulation on the efficiency of PV panel for Niamey (Niger, dry conditions) and Abidjan (Cote d'Ivoire, wet conditions) are presented on section fourth. A general conclusion on the sensitivity of common monocrystalline PV efficiency to West African weather conditions is given on section five.

\subsection{Energetic and Renewable Energy Situation of Niger and Côte d'Ivoire}

\subsubsection{Situation of Niger}

Niger is located between $11^{\circ} 37 \mathrm{~N}$ and $23^{\circ} 33 \mathrm{~N}$ latitude band and between $0^{\circ} 10 \mathrm{~W}$ and $16 \mathrm{E}$ longitude. Niger is a continental country of $1,267,000 \mathrm{~km}^{2}$ whose three-quarter are

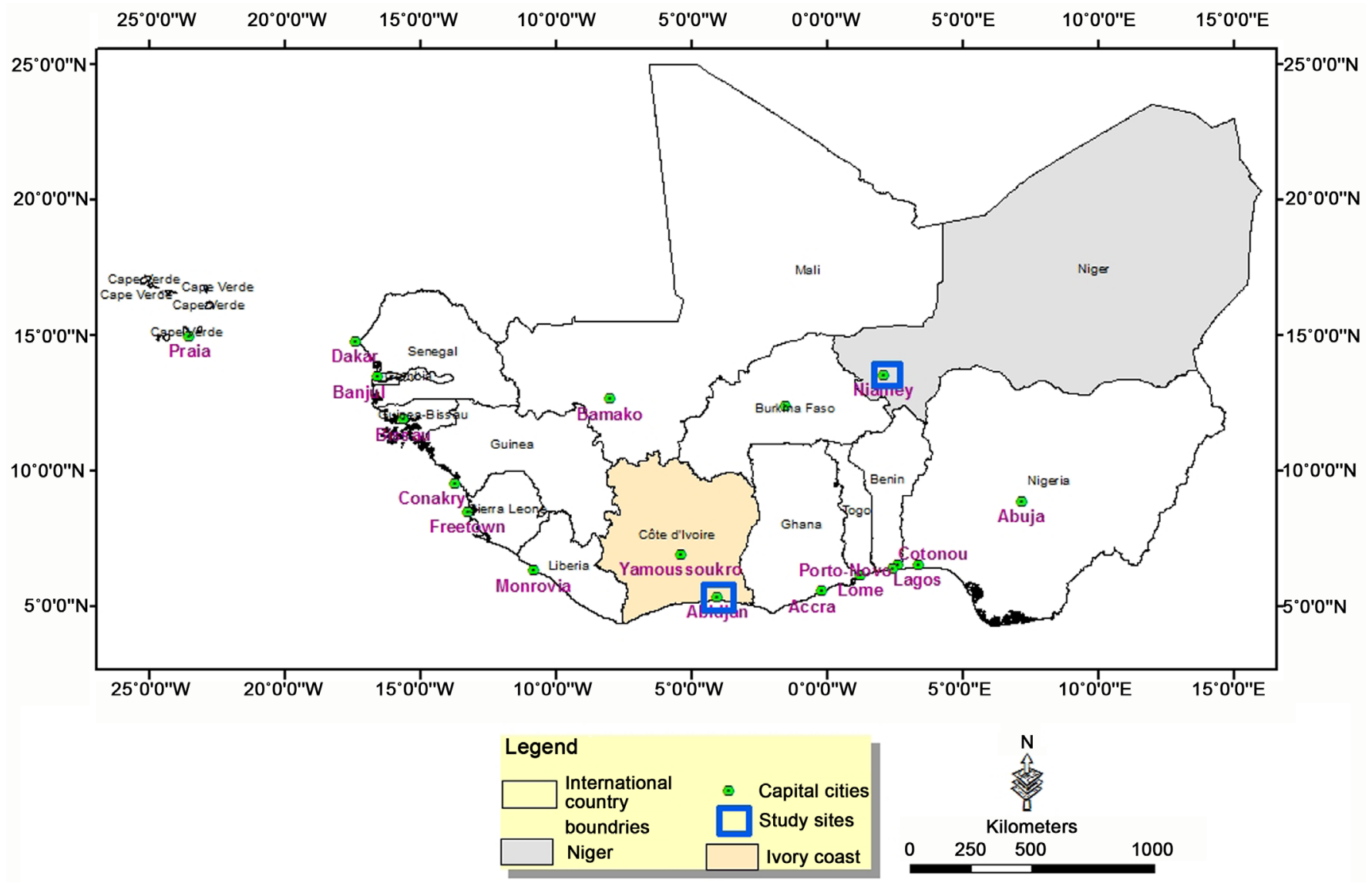

Figure 1. West Africa country map. 
desertic, with an uncertain and very weak pluviometry (frequent droughts and an approximate annual average of $500 \mathrm{~mm}$ ). According to the National Center of Solar Energy, power consumption of Niger is very low, about 1.2 Mtoe/year distributed between wood-fuels from agricultural wood and residues (91\%), petroleum products (7\%), and electricity (2\%) [5]. Wood potential is very low and desertification due to various causes is one of the main concern. The national power production capacity is only 104 MW. However, the country has important resources and energy potentialities. The planed hydroelectric infrastructure powers potentials are 38, 122.5 and $125 \mathrm{MW}$ respectively in Dyodyonga, Gambou and Kandadji. Solar energy potential is extensive: daily insulation ranges from 5 to $6 \mathrm{kWh} / \mathrm{m}^{2} /$ day, and daily insulation duration is about 9 hours. Wind speeds in the country range in average from 2.5 to more than $5 \mathrm{~m} / \mathrm{s}$ [6]. The renewable energy sector is very very low. According to the National Center of Solar Energy, the total PV installed capacity in Niger in 2006, was 1.07 Mega Watt peak (MWp) [5]. A relatively recent study of the national solar energy center CNES, the total capacity in 2014 is estimated to $5.2 \mathrm{MWp}$, with a mean annual increase of $48 \%$ between the two previous periods [5]. This increase is mainly due to an important uses of Solar PV in the sector of telecommunications (for power feed of aerial wires; 39\%), followed by water pumping $(27 \%)$. The remaining ones were for general electrification (including rural areas, $18 \%)$, public lightning (10\%), health centers (5\%), school lightning (1\%). Elsewhere, Niger under-exploits its coal reserves and its natural gas and oil reserves are only recently be proved.

The energy situation in Niger is typical for least advanced countries: only $6.5 \%$ of the people are connected to the electricity grid, and more than $85 \%$ of the primary energy consumed comes from traditional biomass (fuel wood) [5]. Niger is energetically highly dependent on its neighbor Nigeria, who delivers more than half of its electricity (55\%). Authorities and partners, Private organism and NGOs promote and fund the development of solar PV installations. Their fixed goal is to reach $10 \%$ of renewable energy in the national energy consumption by 2020 .

\subsubsection{Situation of Côte d'Ivoire}

Côte d'Ivoire is located within bands latitudes and longitudes $4.4 \mathrm{~N}-10.3 \mathrm{~N}$ and $7 \mathrm{~W}$ 2.8E. Côte d'Ivoire has an area of $322,462 \mathrm{~km}^{2}$ and is bordered by the Atlantic Ocean in the South, and in the North by soudano-sahelian countries such as Burkina Faso and Mali. The country is influenced by two air masses: a moist equatorial air mass called Monsoon and a dry tropical air mass coming along with a northern drying wind named Harmattan, with a saturation of $65 \%-90 \%$. There are four major climate zones in Cote d'Ivoire, namely an equatorial climate, a semi-damp tropical climate, a dry tropical climate and a wet tropical climate. The country knows large temperature variations between the North and the South but also throughout the year depending on the season. The temperatures throughout the year respectively range from a minimum average of $22^{\circ} \mathrm{C}$ to a maximum average of $32^{\circ} \mathrm{C}$.

The net electricity consumption in Abidjan goes up to $4150 \mathrm{GWh}$ in 2009 and it will keep on increasing in the following decades due to high economic growth and increas- 
ing population. The average electricity consumption in urban area is $300 \mathrm{kWh}$ per capita, while it is $150 \mathrm{kWh}$ per capita in rural area. The country main sources of energy are hydropower and thermal. In 2010, hydropower produced $1619 \mathrm{GWh}$ while thermal sources gave $4258 \mathrm{GWh}$. Natural gas is the greatest source of electric power (66.4\%) followed by hydropower (31.2\%), then by biomass with $2.1 \%$ and petroleum with $0.3 \%$ [7]. There is no significant contribution from solar and wind energy sources. Despite the fact that the country is endowed with wind and solar energy potentials, the more exploited renewable energy resources are hydropower (93.5\%) and biomass (6.5\%).

Solar energy is abundant in Cote d'Ivoire, where the average solar radiation ranges between $4 \mathrm{kWh} / \mathrm{m}^{2}$ per day (in the Southern part) and $6 \mathrm{~kW} \mathrm{~h} / \mathrm{m}^{2}$ per day (in the North) with a daily sunshine time of 6 hours.

Figure 2 shows the direct annual solar irradiation in $\mathrm{kWh} / \mathrm{m}^{2} /$ year in Côte d'Ivoire and Niger with the location of Abidjan and Niamey respectively in the Southern part of Côte d'Ivoire and the South Western part of Niger. The northern part of Niger has the largest solar irradiation ranging from 2100 to $2500 \mathrm{kWh} / \mathrm{m}^{2}$ per year while the southern part of Niger which concerns the region of Niamey has relatively small amount of solar irradiation $\left(\leq 1500 \mathrm{kWh} / \mathrm{m}^{2}\right)$. The Northern part of Côte d'Ivoire receives as much solar radiation as the central part of Niger (e.g. ranging from 1500 to $1700 \mathrm{kWh} / \mathrm{m}^{2} /$ year of solar radiation). Concerning our studies areas, on average, Abidjan receives 1000 $\mathrm{kWh} / / \mathrm{m}^{2} /$ year while Niamey receives $1600 \mathrm{kWh} / \mathrm{m}^{2} /$ year.

\subsection{Literature Review and Theoretical Aspects}

\subsubsection{Electrical Characteristics of a PV Cell}

1) Current-Voltage and Power-Voltage curves
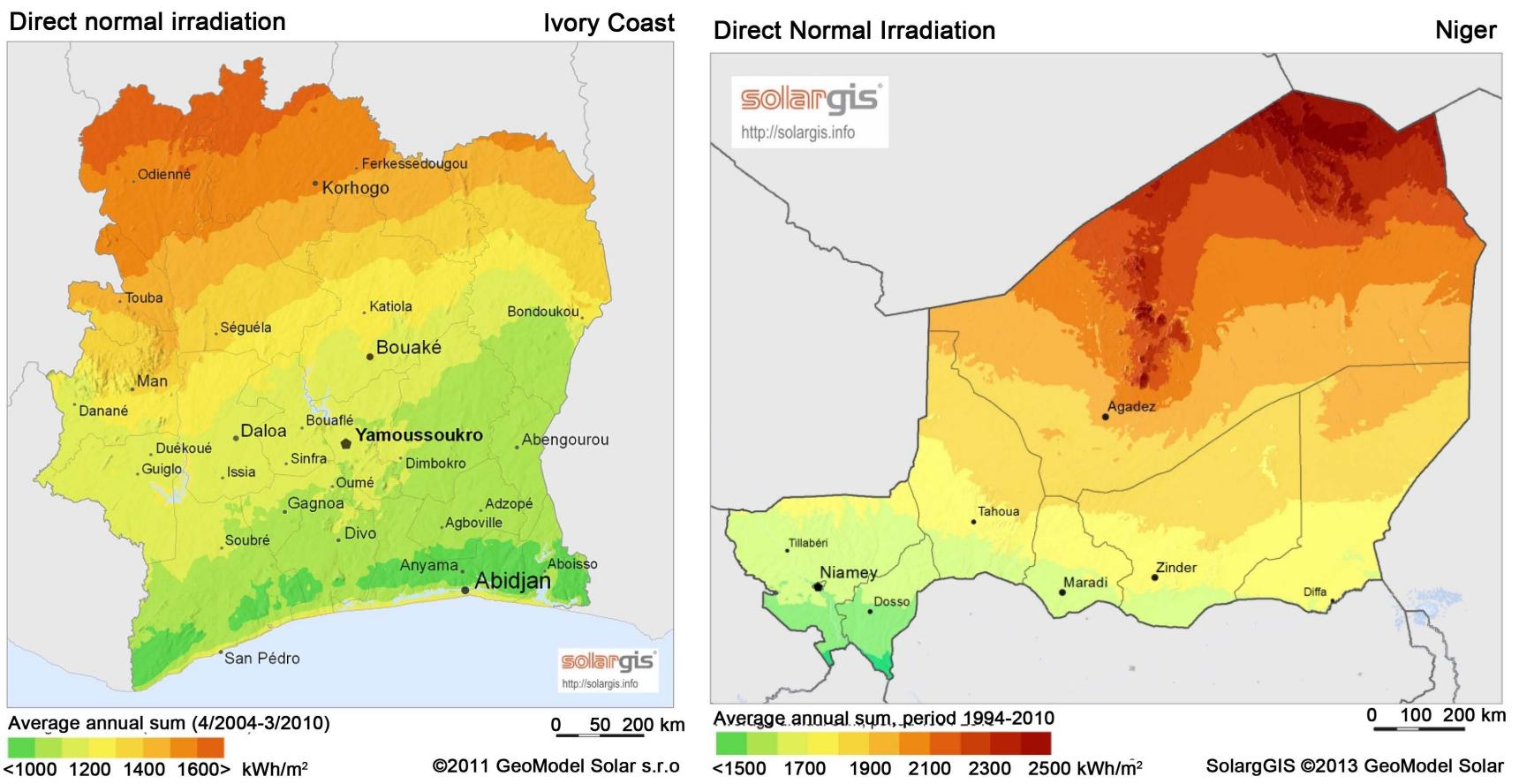

Figure 2. Direct annual solar irradiation in $\mathrm{kWh} / \mathrm{m}^{2} /$ year in Côte d'Ivoire on the left and in Niger on the right (SolarGIS). 
The photovoltaic characteristics (or I-V curve) of a PV module is the important key for identifying its quality and performance as a function of varying environmental parameters [8] [9]. The curve indicates the characteristic parameters of the PV module at which it would work at peak efficiency. These parameters are crucial for designing any small or large PV system. Therefore, it is of utmost importance to measure the I-V characteristics with high accuracy under natural environmental condition [3]. In dark, solar cell I-V characteristics have an exponential pattern similar to a diode [10]. Hence, an ideal solar cell can be represented by a current source connected in parallel with a single diode, as shown in the equivalent circuit of Figure 3 (left). But the ideal case of solar cell not reflect the reality. More accuracy in the model (ideal solar cell) can be achieved by adding series resistances. The configuration of simulated solar cell with single-diode and series resistance is shown in Figure 3 (right).

The photo generated current (Is) is generated by photon and it is proportional to the irradiance G.

$$
I_{s}=a_{s} * G
$$

where $a_{s}$ is a constant

A solar cell can at least be characterized by the short circuit current $I_{s o}$ the open circuit voltage $V_{o c}$ and the diode ideality factor $\mathrm{m}$. For the same irradiance and p-n junction temperature conditions, the short circuit current $I_{s c}$, is the greatest value of the current generated by the cell. The short current $I_{s c}$ is given by:

$$
I_{s c}=I=I_{s} \text { for } V=0
$$

For the same irradiance and $\mathrm{p}-\mathrm{n}$ junction temperature conditions, the open circuit voltage $V_{o c}$ is the greatest value of the voltage at the cell terminal [10]. The open circuit voltage $V_{o c}$ is given by:

$$
V_{o c}=\frac{K_{b} T}{q} \ln \left(1+\frac{I_{s c}}{I_{o}}\right) \quad \text { for } I=0
$$

where $K_{b}$ is the Boltzmann constant, $T$ is the absolute temperature, $q$ positive $(>0)$ is the electron charge, and $V$ is the voltage at the terminals of the cell, and $I_{o}$ is the diode saturation current is also known as the diode reverse bias saturation current. The current voltage and power voltage characteristics curve of an ideal cell are illustrated by Figure 4.
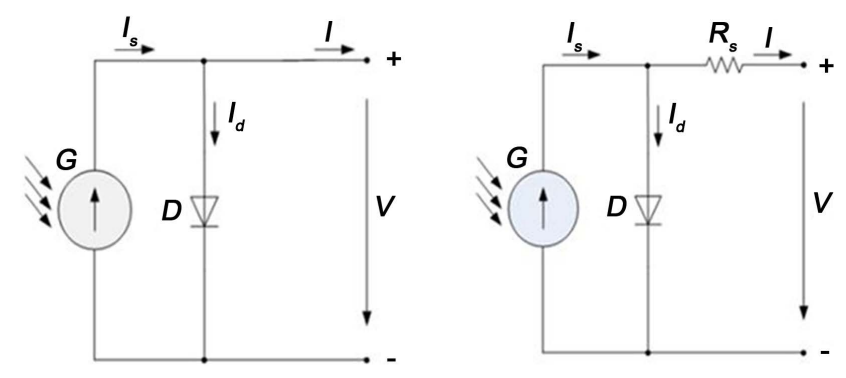

Figure 3. (Left) Ideal solar cell with a single diode and (Right) Ideal solar cell with a single diode and series resistance (Rodrigues et al., 2011) [42]. 


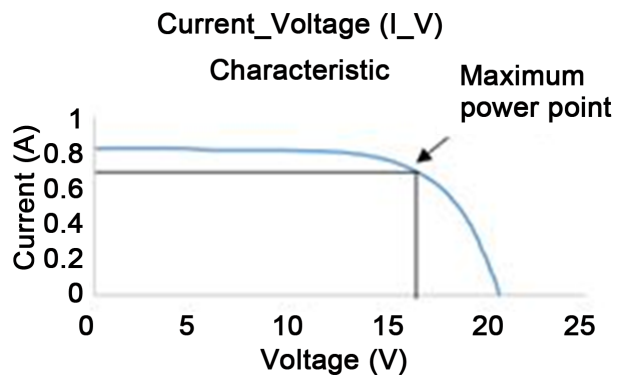

Power_Voltage (P_V) characteristic

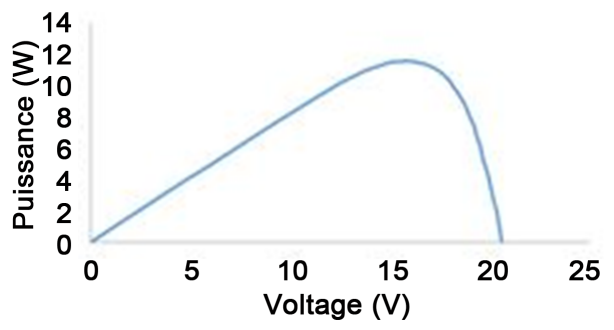

Figure 4. I-V and P-V characteristics.

The I-V curves of a PV string (module) describes its energy conversion capability at an existing condition of irradiance and temperature. Conceptually, the curve represents the combination of current and voltage at which the string could be operated or loaded. Figure 4 shows a typical I-V curve and the P-V curve that is computed from it and key points on these curves. Referring to this figure, the span of the I-V curve range from the short circuit current $\left(I_{s c}\right)$ at zero voltage to zero current at the open circuit voltage $\left(V_{o c}\right)$. The knee of a normal I-V curve is the maximum power point $\left(I_{m p}, V_{m p}\right)$, the point at which the array generates maximum electrical power. At voltage below $V_{m p}$, the flow of solar generate electrical charge to the external load is relatively independent of the output voltage. Near the knee of the curve, this behavior starts to change. As the voltage increases further, an increase percentage of charges recombine within the solar cells rather than flowing out through the load. At $\mathrm{V}_{\mathrm{oc}}$, all the charges recombine internally. The maximum power point $\left(P_{m p}\right)$ located at the knee of the $(\mathrm{I}-\mathrm{V})$ curve is the point at which the product of current and voltage reaches its maximum value.

2) PV Efficiency

The efficiency is the most commonly used parameter to compare the performance of one solar cell to another, i.e. one PV module to another. Expressed in percentage (\%), efficiency $(\eta)$ is defined as the ratio of energy output from the module to input energy from the sun.

The efficiency of a PV module is defined as:

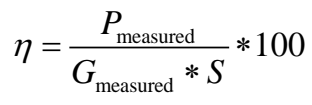

where $P_{\text {measured }}$, the measured power output (W) and $G_{\text {measured }}$ is the measured solar irradiance intensity $\left(\mathrm{W} / \mathrm{m}^{2}\right)$ and $S$ is active area of solar module $\left(\mathrm{m}^{2}\right)$.

The efficiency depends mainly on the spectrum and intensity of the incident sunlight and the temperature of the solar cell. Therefore, conditions under which efficiency is measured must be carefully controlled in order to compare the performance of one device to another. Change in solar modules efficiency is a result of a combination of solar irradiance intensity, ambient temperature, elevation angle of the Sun and local weather conditions [11] [12].

3) Performance Ratio (Pr)

The increasingly common measure of energy production is the performance ratio $\mathrm{Pr}$. The general equation for $\mathrm{Pr}$ is given as: 


$$
P_{r}=\frac{P_{\text {measured }}}{P_{\max (\mathrm{STC})}} * \frac{G_{(\mathrm{STC})}}{G_{\text {measured }}}
$$

where $P_{\text {measured }}$ is the measured power output $(\mathrm{W}), P_{\max (\text { STC })}$ is the maximal rated power at Standard Test Conditions (STC), $G_{(\mathrm{STC})}$, the solar irradiance intensity of 1000 $\mathrm{W} / \mathrm{m}^{2}, G_{\text {measured }}$ is the measured solar irradiance intensity $\left(\mathrm{W} / \mathrm{m}^{2}\right)$. Performance ratio is a site-dependent parameter, which does not take into account temperature or spectral effect. However, it does enable a quantitative comparison of different technologies for a given climate [11] [12] [13] [14].

4) Fill Factor (FF)

Fill Factor is the ratio between nominal and maximum power standard. It is an important indicator of $\mathrm{PV}$ performance. It is given as:

$$
F F=\frac{V_{M P} * I_{M p}}{V_{o c} * I_{s c}}
$$

$V_{M P}$ is the maximal power voltage (the voltage where a module outputs the maximum power) and $I_{M P}$ is the maximum power current, the maximum amperage where a module outputs the maximum power. It shows the influence of the serial resistance on efficiency of solar cell, in other words, it shows how much the solar cell is close to ideal one [11] [12]. Nevertheless, In order to increased power output of a PV system, solar cells are mounted in series and parallels.

\subsubsection{Effect of Tilted Angle on PV Panel Efficiency}

The power incident on a PV module depends not only on the power contained in the sunlight, but also on the angle between the module and the sun rays [15]. When the absorbing surface and the sunlight are perpendicular to each other, the power density on the surface is equal to that of the sunlight. Nevertheless, the best technology of PV enabling the sunlight perpendicular to the PV panels, i.e., the solar tracking systems, are much more expensive than fixed PV systems. However, tilting the surface up, causes the diffuse light to decrease. Thus, in cloudy sky condition, it is better to put the panel horizontally in order to best capture the reflected solar radiation as PV panel work with global radiation. So the best option is to put the PV panel to the optimal tilted angle in order to yield more outputs. A good orientation and tilt angle of PV modules can maximize its energy potential. For the best performance of your systems in the year, in most locations, fixed PV modules should be oriented to true South (in the Northern Hemisphere). In the case that there is no possibility to move the surface of the PV modules at all, the optimal tilt angle for maximum amount of direct irradiance is set out to the site's latitude.

\subsubsection{Effect of PV Cell Temperature (Tcel) on PV Panel Efficiency}

Solar cell temperature is one of the most important factor responsible for lowering the performance of PV modules [16]. It modifies the power output and system efficiency. It depends on the module encapsulating material, the thermal dissipation, the absorption properties, the functioning point of the modules as well as the irradiance intensity, ambient temperature, wind speed and the accurate installation [17]. So it is important to 
perform a quantitative analysis of the temperature influence on PV modules properties such as voltage, current, efficiency under real operating conditions. Thus, increased temperatures affect all PV technologies. But certain types of modules are more resilient to temperature increase than others. Heat also has an effect on panel degradation. Long term exposure to heat will have the panel age more rapidly, while some materials may not be able to withstand short peak of very high temperature [18]. It is possible to cool PV panel either passively through natural air flows or actively, through forced air (ventilation systems and liquids coolants) [19].

\subsubsection{Effect of Ambient Temperature, Irradiance, Wind and Humidity}

It is important to record the performance of PV modules under real climate condition since the outdoor PV electrical characteristics (voltage, current...) are different from those corresponding standard conditions (which are rarely occurs outdoor). The PV modules are rated at standard condition of $1000 \mathrm{~W} / \mathrm{m}^{2}$ of irradiance, $25^{\circ} \mathrm{C}$ of ambient temperature, air mass of 1.5 , and $1 \mathrm{~m} / \mathrm{s}$ wind speed different from outdoor environmental conditions [17]. Despite the fact that irradiation is the main indicator of PV potential, it is also necessary to consider secondary parameters such as PV technology, environmental parameters (wind, temperature, humidity) which allowed us to quantify with precision the amount of electricity produced by a PV system. Based on experimental investigation in Pakistan, it has been reported that monocrystalline silicon modules are more efficient than other modules, but have shown a higher decrease at higher module temperatures [12]. It has investigated that the impact of irradiance and temperature on PV system [20] [21]. They have found that solar irradiance has the greatest impact on the power output of a PV system. Module temperature has significant influence on the behavior of a PV system, as it modifies system efficiency and output energy. Temperature affects how electricity flows through an electrical circuit by changing the speed at which the electrons travel. This is due to an increase in resistance of the circuit that results from an increase in temperature. Likewise, resistance is decreased with decreasing temperatures.

\subsubsection{Effect of Dust on PV Panel Efficiency}

Different studies have been conducted to investigate the effect of dust on solar cells. Dust is defined as particulate matter which size is less than 500 micrometer $(\mu \mathrm{m})$ in diameter. It includes small pollens such as bacteria and microfibers separated from clothes, carpets and the account fungi, fabrics. Dust deposition depends on various environmental and weather conditions. Therefore, pedestrian and vehicular activities, volcanic eruptions, pollution and wind can lift up dust and scatter it into the atmosphere [22]. Dust settlement mainly relies on the dust properties (chemical properties, size, shape, weight, etc.) as well as on the environmental conditions (site specific factors, environmental features and weather conditions) [23]. According to some studies, the surface, tilt angle, humidity and wind speed also affect the dust settlement [22]-[24]. A wide range of reduction in performance have been reported including average reduction of $1 \%$ with a peak of $4.7 \%$ in a two-month period in United States [25], $40 \%$ degradation in a 6 month period in Saudi Arabia [26], 32\% reduction in a 8 month time 
again in Saudi Arabia [22], 17\% - 65\% reduction depending on the tilt angle in 38 days in Kuwait [27]. In another study done in Egypt 33.5\% - 65.8\% reductions in performance have been announced in duration of one to six months exposure [28]. It has been investigated that the impact of humidity, air velocity and dust on solar PV performance [23]. He has confirmed at the end of his investigation that dust deposition and settlement on the surface of PV cells can drop the efficiency.

\section{Research Questions}

How do climatic parameters influence electricity generation of solar PV module?

What is the effect of dust accumulation on solar PV power loss?

\section{Data Collection and Methodology}

The PV panels used for this study are home monocrystalline PV with a peak power of $15 \mathrm{~W}$. These PV are commonly found over the West African markets and distributors. The experiments have been done inside or outside on the roof of the Laboratory of Solar Energy (LES; University Félix Houphouët Boigny in Abidjan $\left(5^{\circ} \mathrm{N} ; 4^{\circ} \mathrm{W}\right)$ and of National Centre of Solar Energy (CNES) in Niamey $\left(13^{\circ} \mathrm{N} ; 2^{\circ} \mathrm{E}\right)$.

The following experiments were conducted to study the sensitivity of PV efficiency to weather conditions and to dust:

- Experiment A: Sensitivity to temperature

o Experiment A1: cell temperature (in Niamey only)

o Experiment A2: Ambient temperature (in Abidjan and Niamey)

- Experiment B: Sensitivity to solar radiation (in Abidjan and Niamey)

- Experiment C: Sensitivity to relative humidity (in Abidjan and Niamey)

- Experiment D: Sensitivity to dust (only in Niamey)

The following instruments: platinum resistance probe, temperature sensor, Eppley PSP pyranometer, hygrometer and variable resistor and multimeters were used to measure respectively the cell temperature, the ambient temperature, the irradiance, the humidity and the electrical parameters, voltage and current delivered by the PV module.

\subsection{Experimental Design for Sensitivity to Humidity and Temperature}

Figure 5 shows the PV panel installed outdoor on the roof of LES in Abidjan from 19 June 2015 to 12 July 2015 and of CNES in Niamey from 22 July 2015 to 22 August 2015.

The technical characteristics of the PV module is given in Table 1.

The experimental set up (Figure 6) is composed with a pyranometer for the measurement of irradiance at the level surface of the module, temperature sensor, variable resistor, and PV power measuring devices (multimeters), to measure voltage and current, and thus to plot the current-voltage (I-V) and the power-voltage (P-V) curves.

In order to have a comparable results, the module was installed under the same condition and the measurements were performed under various conditions of radiation, temperature and humidity for tilt angle of the considered site latitude $\left(5^{\circ}\right.$ for Abidjan and $15^{\circ}$ for Niamey) and on horizontal plane ( $0^{\circ}$ of inclination for both areas of study). 


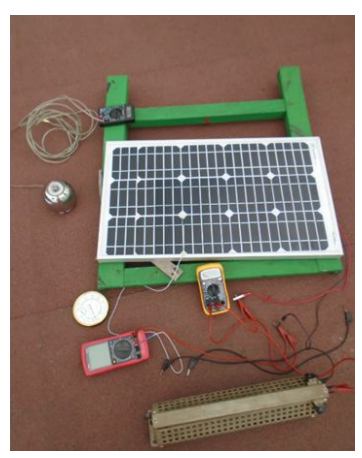

Figure 5. Monocrystalline PV under natural weather conditions (outdoor).

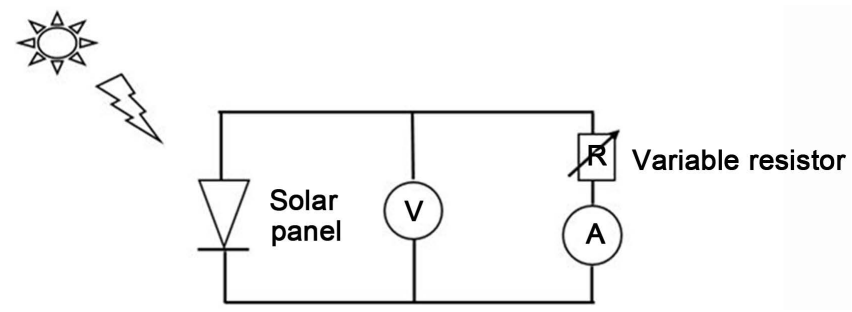

Figure 6. Experimental circuit.

Table 1. Technical characteristics of PV module [29].

\begin{tabular}{|c|c|c|c|c|}
\hline Technology & Manufacturer & Reference & Parameter & Value \\
\hline \multirow{11}{*}{ Monocrystalline } & \multirow{11}{*}{ Eurosolar } & \multirow{11}{*}{ OSP-15 } & Maximum output power $\left(P_{\max }\right)$ & $15 \mathrm{~W}$ \\
\hline & & & Maximum output voltage $\left(V_{\max }\right)$ & $18 \mathrm{~V}$ \\
\hline & & & Maximum output current $\left(I_{\max }\right)$ & $0.88 \mathrm{~A}$ \\
\hline & & & Open circuit voltage $\left(V_{o c}\right)$ & $21.24 \mathrm{~V}$ \\
\hline & & & Short circuit current $\left(I_{s c}\right)$ & $1.11 \mathrm{~A}$ \\
\hline & & & Fill factor (FF) & $67.186 \%$ \\
\hline & & & Weight & $\mathrm{Kg}$ \\
\hline & & & Production Tolerance & \pm 3 \\
\hline & & & Cell area & $145.92 \mathrm{~cm}^{2}$ \\
\hline & & & Active panel area & $0.1915 \mathrm{~m}^{2}$ \\
\hline & & & Panel Dimension: $70 \mathrm{~cm} \times 41$ & $\times 3 \mathrm{~cm}$ \\
\hline
\end{tabular}

The PV module operated under clear, cloudy sky and sunny conditions in order to know the effect of meteorological condition on the efficiency of the PV module.

\subsubsection{Outdoor Experimental Conditions}

The experiment materials are a monocrystalline PV panel of $15 \mathrm{~W}$, a variable resistor from 0 to $100 \mathrm{ohms}(\Omega)$, three digital multimeters (DT170, DT9205 and Unit 107), an Eppley PSP pyranometer and a temperature sensor. We also use a platinum resistance probe to measure the resistance of the PV modules and thus, to determine the cell 
temperature $\left(T_{\text {noct }}\right)$. It is made of a thin film of platinum with resistance varying from 0 to $100 \Omega$. The precision of this probe depends on the temperature range as indicated by the NFC C42-330, DIN 4376 and BS 1904 norms.

$> \pm 1^{\circ} \mathrm{C}$ from $0^{\circ} \mathrm{C}$ to $150^{\circ} \mathrm{C}$

$> \pm 0.70^{\circ} \mathrm{C}$ from $150^{\circ} \mathrm{C}$ to $500^{\circ} \mathrm{C}$

For determining the temperature of the PV cell $\left(T_{\text {noct }}\right)$, we proceeded to a calibration, which consisted of putting both a thermometer and a platinum probe in a warm water and recorded for each value of resistance, the corresponding temperature. Then by the least squares method, we determine the linear regression line $(R=a T+b)$ between resistance and temperature of the PV cell. It is shown as the Figure 7.

The result of the calibration method and the equation of the linear relationship are given in the Equation (7). The correlation coefficient of the linear regression is equaled to 0.9979 ; the obtained equation is:

$$
R=0.435 T+96.995
$$

The description of the principle of the experiment are explained as follow:

Lighten the PV modules by placing it under the sunshine at different position (horizontal or tilt angle).

Measure the irradiance using the pyranometer at the place where the PV was set.

$>$ Wait for one minute to ensure the well-functioning of the system to avoid error due to temperature variation.

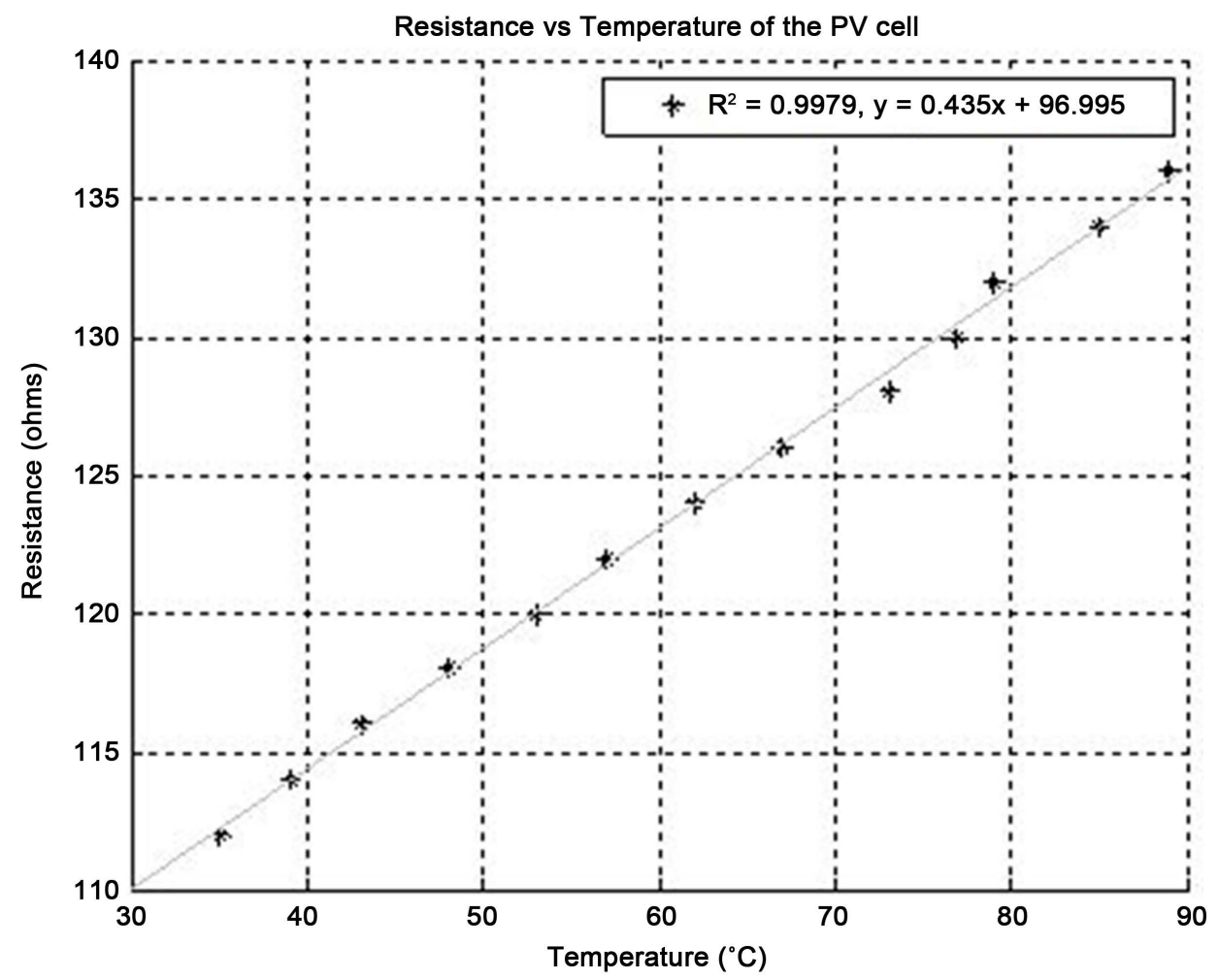

Figure 7. Linear regression plot of the resistance $=\mathrm{f}($ Tcel $)$. 
Make sure that during all the phase of measurement, the value of irradiance is constant on the PV module.

Measure the open circuit voltage $\left(V_{o c}\right)$ and the short-circuit current $\left(I_{s c}\right)$, then for different values of resistance, from 100 to $0 \Omega$, measure the voltage $V$ at the edge of the PV panel and the intensity in the circuit for about 10 values.

Gather all the data in a table; voltage (sorted from the largest to the smallest) in function of current. Complete the table by computing the power obtained by $(P=U * I)$ and then plot the characteristics Current-voltage $(I=f(U))$ and Power-voltage $(P=f(U))$.

$>$ Identify the functioning point of the PV panel such as maximum power $\left(P_{m}\right)$, open circuit voltage $\left(V_{o c}\right)$, short-circuit current $\left(I_{s c}\right)$. Do the measurement for several values of irradiance and under sunny and cloudy conditions to see how maximum power delivered by the PV varies with the incoming solar radiation.

Table 2 is an example of data recorded in outdoor conditions over Abidjan on 1 July 2015 for a given irradiance $\left(797.31 \mathrm{~W} / \mathrm{m}^{2}\right)$. Figure 8 gives the corresponding $\mathrm{I}-\mathrm{V}$ and $\mathrm{P}-\mathrm{V}$ curves that enable to compute the efficiency.
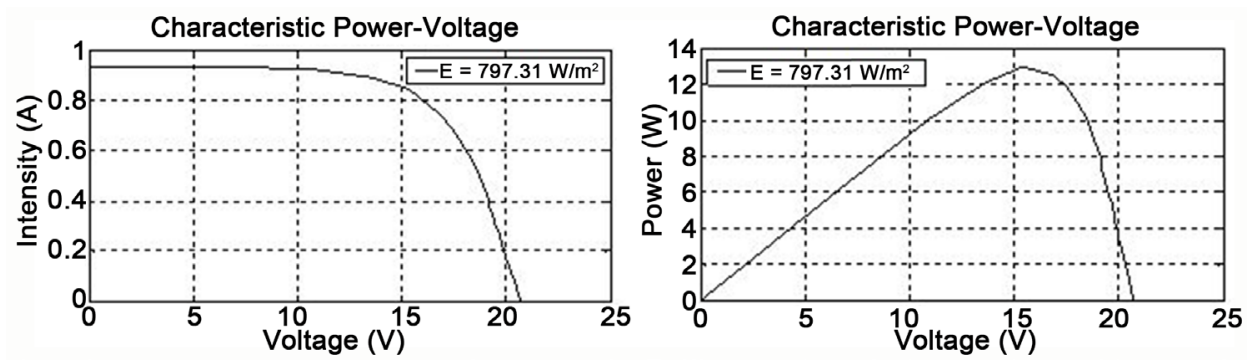

Figure 8. Corresponding I-V and P-V curves of PV module in outdoor conditions.

Table 2. Data recorded from outdoor condition experiment.

\begin{tabular}{cccccccc}
\hline $\mathbf{N}^{\circ}$ & Voltage (V) & Current (A) & Power (W) & $\mathbf{N}^{\circ}$ & Voltage (V) & Current (A) & Power (W) \\
\hline 1 & 20.7 & 0.0 & 0.00 & 14 & 18.5 & 0.54 & 9.990 \\
2 & 20.3 & 0.1 & 2.03 & 15 & 18.1 & 0.60 & 10.860 \\
3 & 20.2 & 0.12 & 2.424 & 16 & 27.5 & 0.68 & 11.900 \\
4 & 20.1 & 0.15 & 3.015 & 17 & 16.9 & 0.74 & 12.506 \\
5 & 20.0 & 0.17 & 3.400 & 18 & 25.4 & 0.84 & 12.996 \\
6 & 19.9 & 0.21 & 4.179 & 19 & 15.1 & 0.85 & 12.835 \\
7 & 19.8 & 0.22 & 4.356 & 20 & 13.6 & 0.89 & 12.104 \\
8 & 19.7 & 0.27 & 5.319 & 21 & 10.9 & 0.92 & 10.028 \\
9 & 19.5 & 0.30 & 5.850 & 22 & 8.0 & 0.93 & 7.440 \\
10 & 19.4 & 0.33 & 6.402 & 23 & 4.5 & 0.93 & 4.185 \\
11 & 19.2 & 0.38 & 7.296 & 24 & 3.3 & 0.93 & 3.069 \\
12 & 19.1 & 0.42 & 8.022 & 25 & 1.0 & 0.93 & 0.930 \\
13 & 18.9 & 0.46 & 8.694 & 26 & 0.2 & 0.93 & 0.186
\end{tabular}


The efficiency of the PV for several values of solar radiation associated with different atmospheric conditions (sunny, cloudy and overcast)and climatic parameters (temperature, solar radiation and humidity) is computed both in Abidjan and Niamey. Finally, idealized indoor experiments have been performed to investigate the sensitivity of PV efficiency to different radiation with constant values of temperature and humidity.

\subsubsection{Indoor Experimental Conditions}

This experiment was conducted indoor at LES Laboratory (Abidjan) using an incandescent bulb (Tungsten) of $1000 \mathrm{~W}$ to lighten the PV module place at a variable distance respectively $(20,15,10$ and 5 centimeters) of the panel in order to fix different irradiances (respectively $211 \mathrm{~W} / \mathrm{m}^{2}, 384 \mathrm{~W} / \mathrm{m}^{2}, 576 \mathrm{~W} / \mathrm{m}^{2}$ and $893 \mathrm{~W} / \mathrm{m}^{2}$ ). Tungsten filaments radiate mostly infrared radiation at temperatures below 3244 degrees Celsius. Measurement of $\left(I_{s c}\right),\left(V_{o c}\right),\left(P_{m}\right)$ has been recorded, thus I-V and P-V characteristics curves of PV module has been plotted in order to compute the efficiency in such condition for each value of irradiance. Figure 9 shows the indoor experimental condition.

\subsection{Experimental Design for Sensitivity to Dust}

As illustrated in Figure 10, the sensitivity of PV efficiency to dust has been conducted at CNES by using two identical PV, one has been cleaned every day (right) and the other neglected (left) for a period of three weeks (from 3 to 23 September 2015).

The electrical and technical characteristics of these PV are given in Table 3.

The dust experiment consisted on putting the two identical PV under the same condition; while cleaning one every day, the other one is not cleaned during three weeks. The two PV have been placed with a tilt angle of $15^{\circ}$, according to the latitude of the Niamey site. They have been connected in parallel to two multimeters which give measurement of $I_{s c}, V_{o c}$ of the PV at any time when sunshine strikes on the PV panel. A pyranometer has been placed at the same location to record the solar radiation,

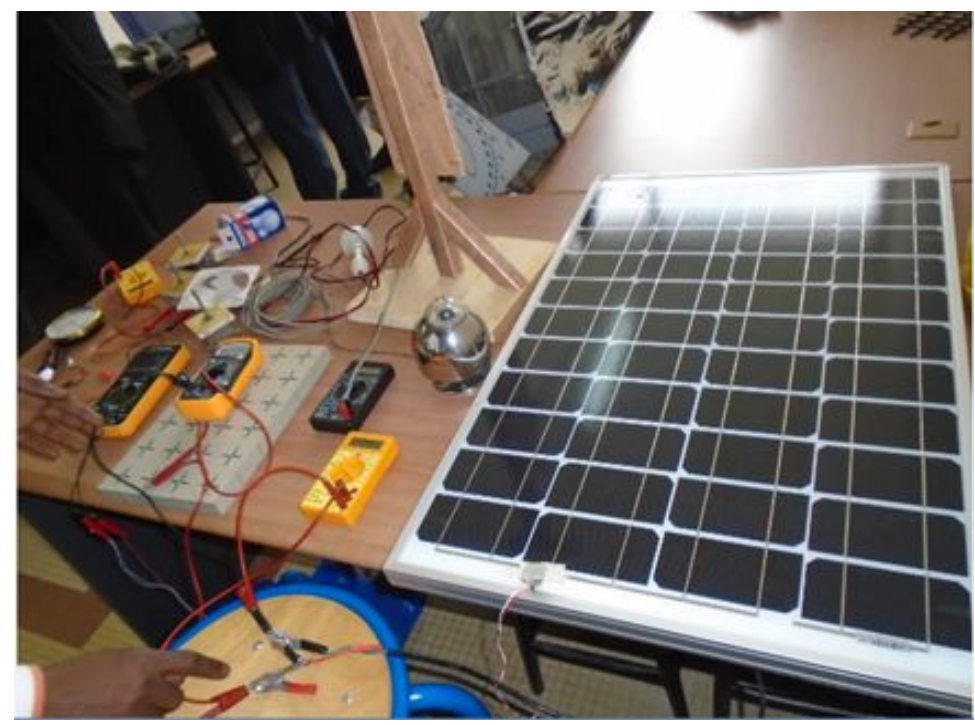

Figure 9. Indoor experimental conditions. 


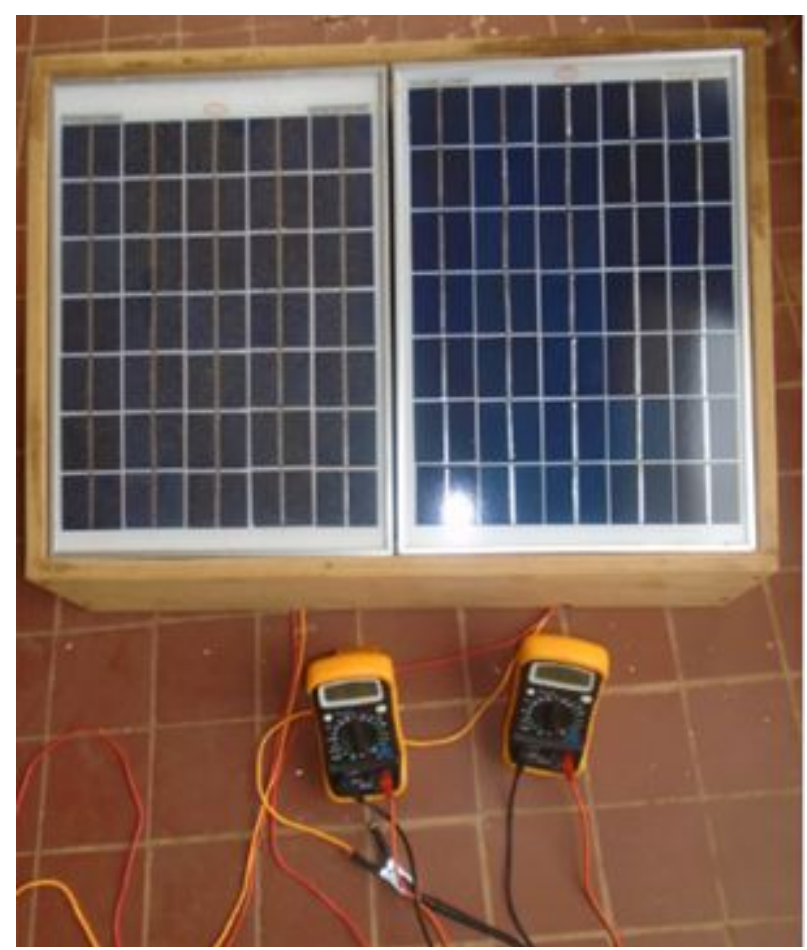

Figure 10. Photos of the PVs during dust experiment with the left one not cleaned during 3 weeks.

Table 3. Technical characteristics of PV module [30].

\begin{tabular}{|c|c|c|c|c|}
\hline Technology & Manufacturer & Reference & Parameter & Value \\
\hline \multirow{11}{*}{ Polycrystalline } & \multirow{11}{*}{ Sunshine Solar } & \multirow{11}{*}{ AP-PM-15 } & Maximum output power $\left(P_{\max }\right)$ & $15 \mathrm{~W}$ \\
\hline & & & Maximum output voltage $\left(V_{\max }\right)$ & $17.5 \mathrm{~V}$ \\
\hline & & & Maximum output current $\left(I_{\max }\right)$ & $0.85 \mathrm{~A}$ \\
\hline & & & Open circuit voltage $\left(V_{o c}\right)$ & $22.05 \mathrm{~V}$ \\
\hline & & & Short circuit current $\left(I_{s c}\right)$ & $0.95 \mathrm{~A}$ \\
\hline & & & Fill factor (FF) & $71.0108 \%$ \\
\hline & & & Weight & $1.5 \mathrm{~kg}$ \\
\hline & & & Production Tolerance & \pm \\
\hline & & & Cell area & $0.084 \mathrm{~m}^{2}$ \\
\hline & & & Active panel area & $0.1239 \mathrm{~m}^{2}$ \\
\hline & & & \multicolumn{2}{|c|}{ Panel Dimension: $42 \mathrm{~cm} \times 29.5 \mathrm{~cm} \times 2.3 \mathrm{~cm}$} \\
\hline
\end{tabular}

thus enable the computation of the performance ratio of the two modules. Table 4 gives a sample of the data recorded through this experiment.

The recorded parameters are day of experiment, hour, incoming solar radiation $\left(\mathrm{W} / \mathrm{m}^{2}\right)$, short-circuit current $\left(I_{s c 1}\right)$, open-circuit voltage $\left(V_{o c 1}\right)$ for the uncleaned PV module, $P_{1}$, the power produced $\left(P_{1}=I_{s c 1} * V_{o c 1}\right)$, short-circuit current $\left(I_{s c 2}\right)$, open-circuit voltage $\left(V_{o c 2}\right)$ for the cleaned PV module, $P_{2}$, the power produced $\left(P_{2}=I_{s c 2} * V_{o c 2}\right)$, the power difference and the relative difference which is the ratio of the difference of power for the two modules and the power of the cleaned module. 
Table 4. Sample of data recorded for dust experiment for one day test.

\begin{tabular}{cccccccccccc}
\hline Day & Hour & $\begin{array}{c}\text { Radiation } \\
\left(\mathrm{W} / \mathrm{m}^{2}\right)\end{array}$ & $V_{o c 1}(\mathrm{~V})$ & $I_{s c 1}(\mathrm{~A})$ & $P_{1}(\mathrm{~W})$ & $V_{o c 2}(\mathrm{~V})$ & $I_{s c 2}(\mathrm{~A})$ & $P_{2}(\mathrm{~W})$ & $\begin{array}{c}\text { Difference } \\
\text { of Power }\end{array}$ & $\begin{array}{c}\text { Relative } \\
\text { Difference }\end{array}$ \\
\hline $23 / 09 / 2015$ & $9 \mathrm{~h} 50$ & 722 & 19,75 & 0.61 & 12.05 & 20.00 & 0.65 & 13.00 & 0.95 & $7.33 \%$ \\
$23 / 09 / 2015$ & $11 \mathrm{~h} 00$ & 918 & 18.18 & 0.75 & 13.64 & 18.41 & 0.80 & 14.73 & 1.09 & $7.42 \%$ \\
$23 / 09 / 2015$ & $12 \mathrm{~h} 00$ & 992 & 17.94 & 0.79 & 14.17 & 18.27 & 0.84 & 15.35 & 1.17 & $7.65 \%$ \\
$23 / 09 / 2015$ & $13 \mathrm{~h} 00$ & 966 & 17.98 & 0.76 & 13.66 & 18.30 & 0.81 & 14.82 & 1.16 & $7.81 \%$ \\
$23 / 09 / 2015$ & $14 \mathrm{~h} 05$ & 852 & 18.20 & 0.73 & 13.29 & 18.43 & 0.78 & 14.38 & 1.09 & $7.58 \%$ \\
$23 / 09 / 2015$ & $14 \mathrm{~h} 06$ & 845 & 18.19 & 0.72 & 13.10 & 18.42 & 0.78 & 14.37 & 1.27 & $8.84 \%$ \\
$23 / 09 / 2015$ & $15 \mathrm{~h} 05$ & 632 & 18.20 & 0.58 & 10.56 & 18.49 & 0.64 & 11.83 & 1.28 & $10.80 \%$ \\
$23 / 09 / 2015$ & $16 \mathrm{~h} 06$ & 382 & 18.05 & 0.41 & 7.40 & 18.38 & 0.46 & 8.45 & 1.05 & $12,46 \%$ \\
\hline
\end{tabular}

\section{Results and Discussion}

\subsection{Experiment A1: Variation of PV Efficiency to Cell Temperature}

This experiment was done only in Niamey due to the availability of the measurement instrument. The sensitivity of PV to cell temperature is presented in Figure 11.

Figure 11 shows that for high cell temperature $T_{c}$ values (above $50^{\circ} \mathrm{C}$ ), the PV efficiency start decreasing. PV silicon technologies are sensitive to cell temperature increases. However, some technologies are more resilient than others. In fact, as cell temperature increases, the band gap of intrinsic semi-conductor shrinks, the opencircuit voltage decreases following the $\mathrm{p}-\mathrm{n}$ junction voltage temperature, which contains a diode factor $\left(a=q / K_{b} T\right)$. Likewise, that causes a lower power at a given photocurrent. The reduction in open-circuit voltage $\left(V_{o c}\right)$ results in a decreasing of the theoretical maximum power $\left(P_{\max }\right)$ at a particular short-circuit current $\left(I_{s c}\right)$. Secondly, as temperature increases, the band gap shrinks and we have more absorption of incident light which leads to a slight increasing in the short-circuit current $\left(I_{s c}\right)$. Consequently, increasing cell temperature leads to a decreasing in $\left(V_{o c}\right)$ and slightly increasing in $\left(I_{s c}\right)$, eventually result in reducing power output [31].

\subsection{Experiment A2: Variation of PV Efficiency to Ambient Temperature}

Figure 12 presents the variations of PV efficiency versus ambient temperature.

These plots present respectively the efficiency versus ambient temperature for Abidjan, and Niamey. In Abidjan (plot a), due to few temperature variation, relatively reduced temperature range, we observed any trend between PV efficiency and ambient temperature. For all the measurements, measured ambient temperatures are below $30^{\circ} \mathrm{C}$, whereas in Niamey, the measurements ranged from $25^{\circ} \mathrm{C}$ to $40^{\circ} \mathrm{C}$. We have observed in Niamey that all the points below $33^{\circ} \mathrm{C}$ are scattered, slightly liked observed behavior for Abidjan, while for temperatures above $33^{\circ} \mathrm{C}$, the points are regrouped and are following a defined trend. For this reason, Niamey measured data were splited into two parts. Figure 13 shows the plots of PV efficiency for temperature below $33^{\circ} \mathrm{C}$ (left) and for temperature above $33^{\circ} \mathrm{C}$ (right). 


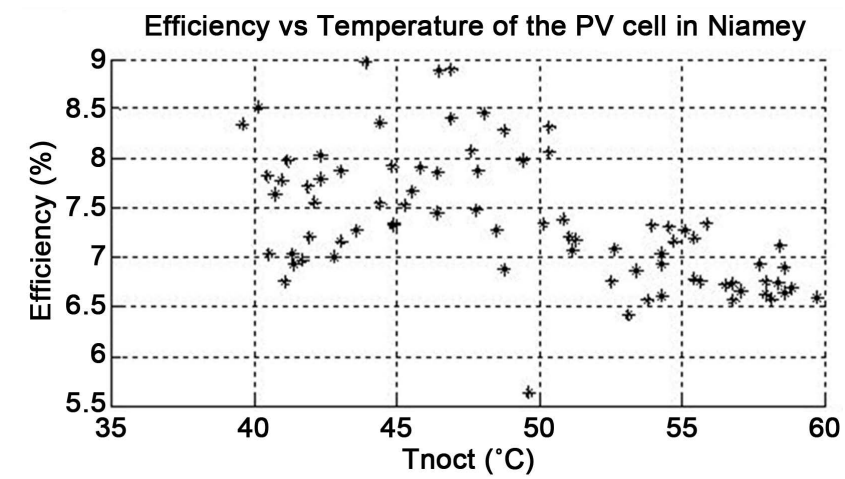

Figure 11. PV efficiency versus cell temperature (Tc).

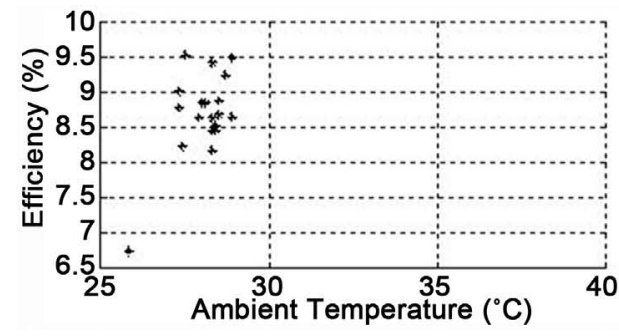

(a)

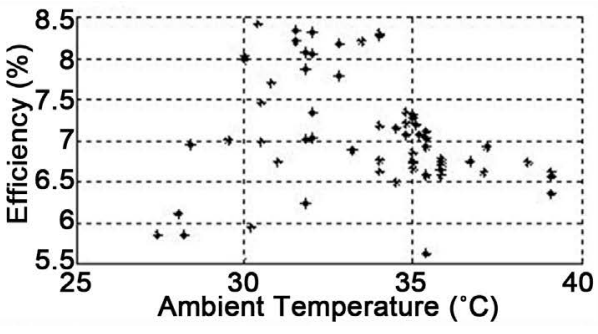

(b)

Figure 12. PV efficiency versus ambient temperature in Abidjan (a) and Niamey (b).
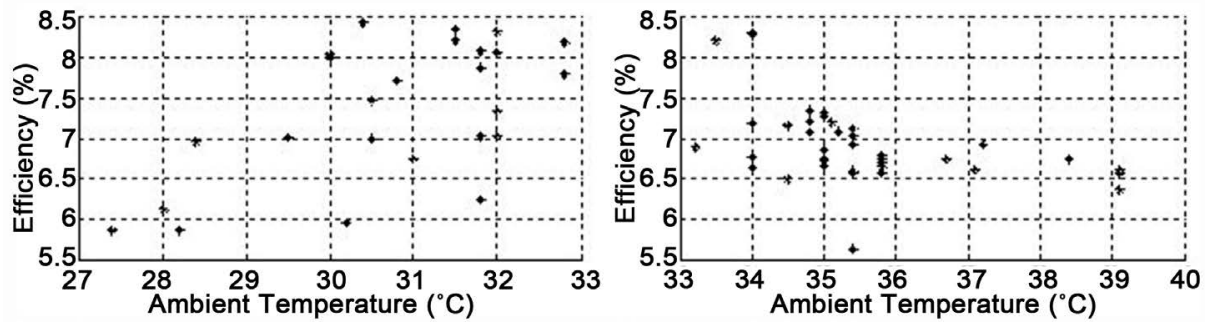

Figure 13. PV efficiency versus ambient temperature in Niamey: For temperature between $27^{\circ} \mathrm{C}$ $32^{\circ} \mathrm{C}$ (left) and for temperature from $33^{\circ} \mathrm{C}$ to $39^{\circ} \mathrm{C}$ (right).

We have observed in the Figure 13 that the PV efficiency does not well correlate with ambient temperature for temperature ranging from $27^{\circ} \mathrm{C}$ to $32^{\circ} \mathrm{C}$. However, the general trend of the obtained results indicates the efficiency increases in this range. For relatively high ambient temperatures values (above $32^{\circ} \mathrm{C}$ ), a significant decrease of the PV efficiency is observed. Several studies have demonstrated that PV technologies, operating in warm climates are subjected to increase of cell temperature and to related efficiency fluctuations [32] [33]. In fact, temperature affects how electricity flows through an electrical circuit by changing the speed at which electrons travel. From this result, we can conclude that under West-African environment conditions, PV panels are more efficient at relatively lower ambient temperature conditions. When ambient temperature is relatively high, PV cells experience an increase of cell temperature, resulting in the PV efficiency reduction. A study made in Tripura (India) showed similar result for the same monocrystalline PV technology [34]. Therefore, PV panels efficiency in West- 
Africa highly depends on the concern climatic zones. Moreover, in Sahelian environment, like Niger, even in a climatic zone, the nature of the season (dry, rainy and cold) can influenced drastically the PV efficiency. In order to have a clear idea of PV panels performances in West-Africa, further climatic zones and seasons impacts investigation will be needed.

\subsection{Experiment B: Variation of PV Panel's Efficiency with Solar Radiation}

Figure 14 shows the relationship between short-circuit current $\left(I_{s c}\right)$ and the incoming solar radiation respectively in Abidjan and Niamey. We can observe that there is a strong correlation between the short-circuit current and the solar radiation $\left(R^{2}=0.95\right.$ for Abidjan and $R^{2}=0.99$ for Niamey). The linear equation of $I_{s c}=f$ (radiation) is $y$ $=0.0011 x+0.0387$ and $y=0.001 x+0.0476$ respectively for Abidjan and Niamey.

The observed results can partly be explained by the fact, the short circuit current is proportional to the current generated $\left(I_{s}\right)$ due to the photoelectric effect (Cf Equation (1)).

$$
I_{s c}=-\left\{I_{0}\left[\exp \left(\frac{q V}{k_{b} T}\right)-1\right]-I_{s}\right\}=-\left(I_{d}-I_{s}\right)
$$

At $V=0$, with equation 1 , we have

$$
I_{s c}=I_{s}=a_{s} E
$$

where $I_{d}=I_{0}\left[\exp \left(\frac{q V}{K_{b} T}\right)-1\right]$ is the diode current.

$>I_{0}$ is the saturation current

$>q$ is the electron charge, $1.602 \times 10^{-23} \mathrm{C}$

$>k_{b}$ is the Boltzmann constant, $1.38 \times 20^{-23} \mathrm{~J} / \mathrm{K}$

$>V$ is the voltage

$>T$ is the Temperature

$>I_{s}$ is the photocurrent and $E$ is the solar radiation.

Thus, for a fixed value of irradiance, it seems that photocurrent generated $\left(I_{s}\right)$ is higher in Abidjan than in Niamey. However, the efficiency of a PV module is computed from the maximum power point which is the maximum current $\left(I_{\max }\right)$ times the maximum voltage $\left(V_{\max }\right)$ values obtained at a nominal functioning point of a PV module. Figure 15 illustrates the efficiency versus solar radiation for both study areas.
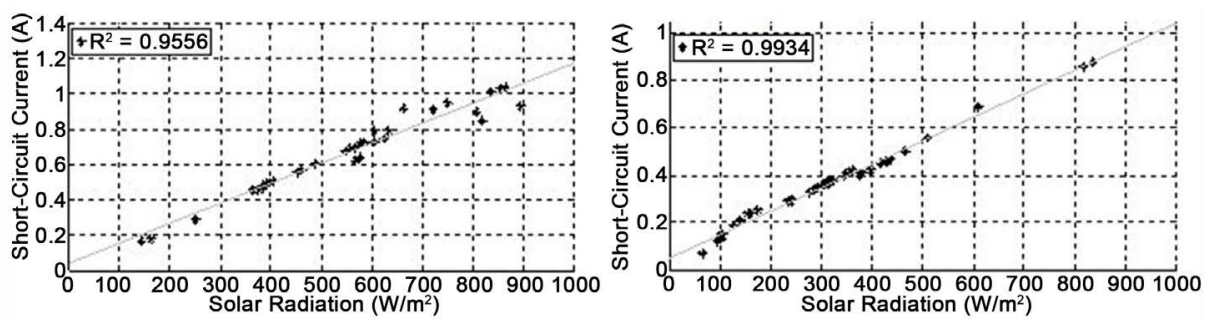

Figure 14. Short-circuit current (Isc) versus solar radiation over Abidjan (left) and Niamey (right). 

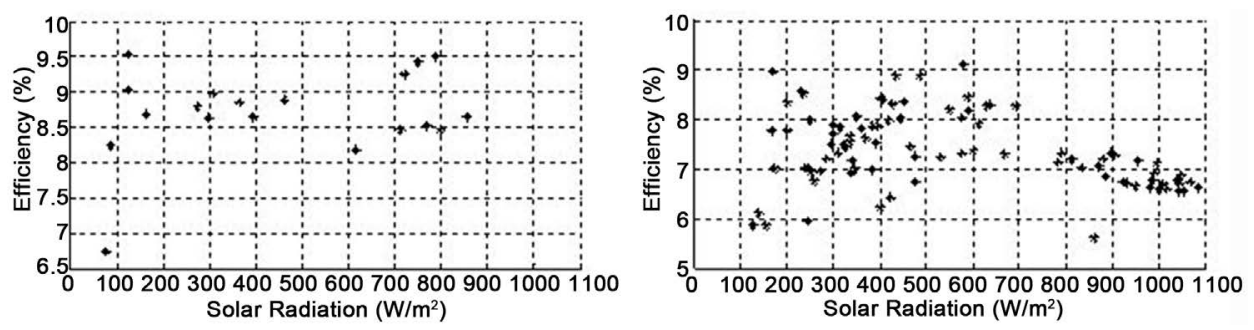

Figure 15. Efficiency versus solar radiation for Abidjan (left) and Niamey (right).

Figure 15 shows weak relationship between the efficiency and the radiation both in Abidjan (weak correlation coefficient $\left.R^{2}=0.0638\right)$ and Niamey $\left(R^{2}=0.1144\right)$ for a solar radiation within the range from 100 to $600 \mathrm{~W} / \mathrm{m}^{2}$. This can be explained by the fact that the efficiency is equal to:

$$
\eta=\frac{V_{m} I_{m}}{E * S}=\frac{V_{m} I_{m}}{V_{o c} * I_{s c}} * \frac{V_{o c} * I_{s c}}{E * S}=F F * \frac{V_{o c} * I_{s c}}{E * S}
$$

For a constant fill factor $(F F)$, the Equation (10) becomes:

$$
\eta=\frac{F F * a_{s} * V_{o c}}{S}=a_{o c} * V_{o c}
$$

where $a_{o c}=\frac{a_{s} * F F}{S}$

In other part, $V_{o c}$ is given by the following equation,

$$
V_{o c}=\frac{K_{b} * T}{q} \ln \left[\frac{I_{s c}}{I_{o}}+1\right]
$$

Or:

$$
V_{o c}=\frac{K_{b} * T}{q} \ln \left[\frac{I_{s}}{I_{o}}\right]
$$

Thus Equation (11) becomes

$$
\eta=\frac{a_{o c} * K_{b}}{q} T \ln \left(1+\frac{I_{s c}}{I_{o}}\right)=a_{1} T \ln \left(1+\frac{I_{s c}}{I_{o}}\right)
$$

where $a_{1}=\frac{a_{o c}}{q}=\frac{a_{s} F F}{q S}$

Given that $I_{o} \ll I_{s c}$ (for good solar cells, $I_{o} \approx 10^{-8} \mathrm{~A} \cdot \mathrm{m}^{-2}$, [35] and with the formulation of Equation (9), the equation can be rewritten as

$$
\eta=a_{1} T \ln \left(\frac{a_{s}}{I_{o}} E\right)=a_{1} T \ln \left(a_{2} E\right)
$$

where $a_{2}=\frac{a_{s}}{I_{o}}$.

According to these formulations, the relationship between efficiency and irradiance is not linear. However, the result of plot (d) in Figure 16 shows that over Niamey at high irradiance level (up to $600 \mathrm{~W} / \mathrm{m}^{2}$ ), the efficiency decreases with the solar radiation 

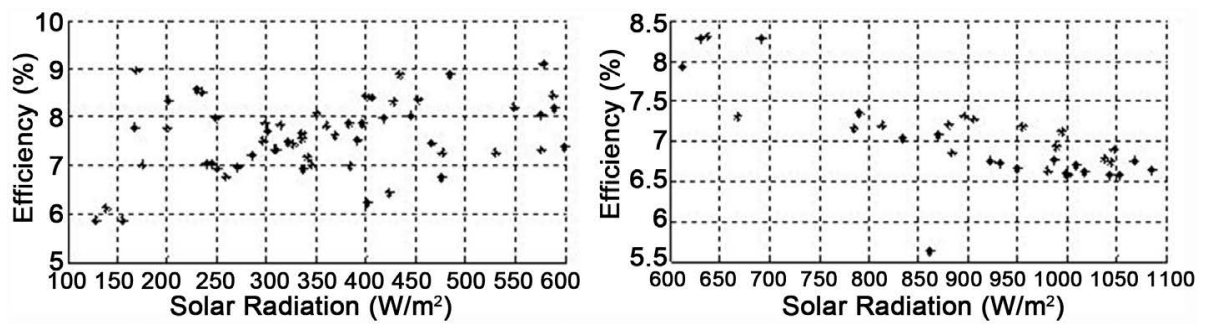

Figure 16. PV efficiency in Niamey versus solar radiation below $600 \mathrm{~W} / \mathrm{m}^{2}$ (left) and above 600 $\mathrm{W} / \mathrm{m}^{2}$ (right).

$\left(R^{2}=0.48\right)$. These results are similar to some studies [36]. It has been of course observed in Nigeria that efficiency, $V_{\max }, V_{o c}$, and $F F$ significantly decreases for irradiances above $600 \mathrm{~W} / \mathrm{m}^{2}$. Result has showed a decrease for all of the three PV technologies but not at the same level.

This may be explained by the fact that the Equation (8) is validated for mean values of irradiance, but at high irradiance level, the equation became [37]

$$
\begin{gathered}
I_{s c}=\left(I_{o}\left[\exp \left(\frac{q V_{o c}}{K T}\right)-1\right]\right) \\
V_{o c}=\frac{K * T}{q} \ln \left[\frac{I_{s}}{I_{o}}+1\right] \\
I_{o}=A_{o} T^{3} \exp \left(\frac{E}{K T}\right)
\end{gathered}
$$

As $V_{o c}$ depends strongly on the operating cell temperature, which increases with high irradiance because not all the incoming solar radiation is convert into light, there is also infrared radiation which contributes to heat up the material while solar radiation increases. Thus, high radiation increases $T_{\mathcal{c}}$, which leads to decrease $V_{o c}$, and affects the efficiency of the PV module.

\subsection{Experiment C: Variation of PV Efficiency with Relative Humidity}

Figure 17 illustrates the variation of PV efficiency with respect to relative humidity.

Figure 18 shows for the two localities the efficiency versus relative humidity after 10 days and one day (11 July 2015) measurements. A decrease of efficiency with relative humidity is observedin both towns, Abidjan and Niamey. The correlation coefficient is relatively higher for one day measurement $\left(R^{2}=0.6397\right.$ in Abidjan, $R^{2}=0.5975$ in Niamey) than for several day measurements (for 10 days, $R^{2}=0.3933$ in Abidjan, $R^{2}=$ 0.0407 in Niamey). These results are in agreement with some study conducted in India, [34] in Qatar [38] and in Oman [39] for the same technology (monocrystalline PV module). According to previous studies, the effect of humidity can be divided into two: effect of water vapor particles on the irradiance level of sunlight and second humidity ingression to the solar cell enclosure [23]. When light hits water droplets, it may be refracted, reflected or diffracted. These effects decrease the amount of direct component of solar radiation received. Humidity changes the irradiance non-linearly and irra- 

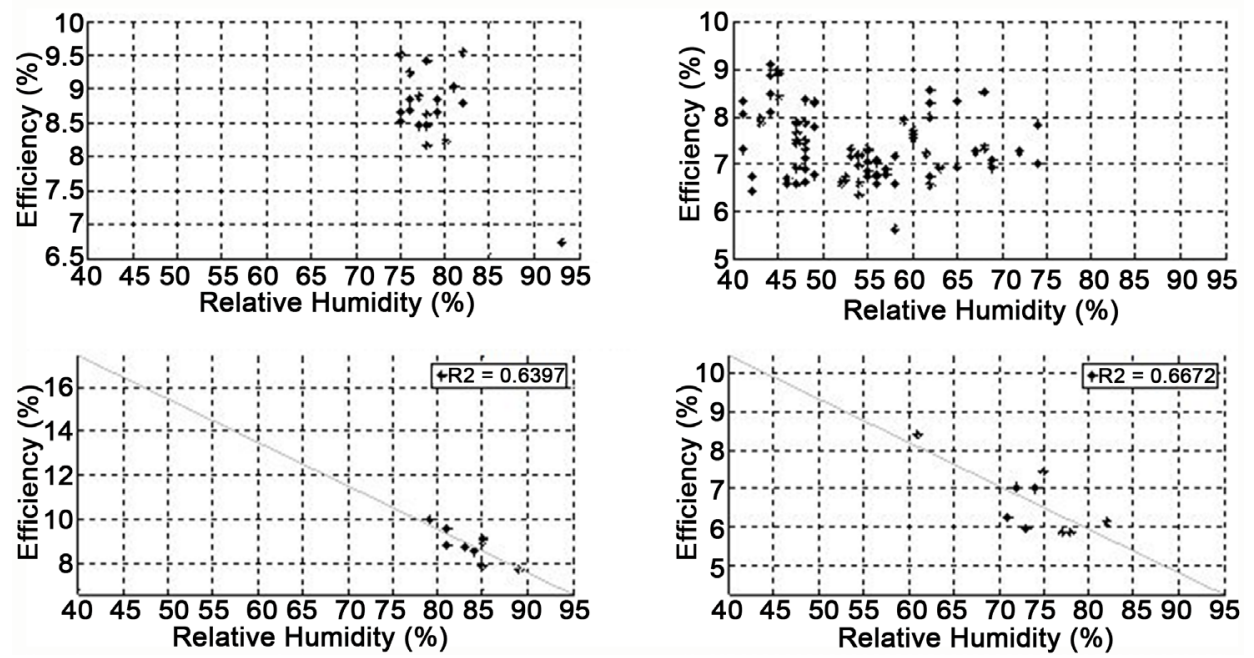

Figure 17. Efficiency versus relative humidity after 10 days (left) and one day (right) measurements over Abidjan (top) and Niamey (bottom).

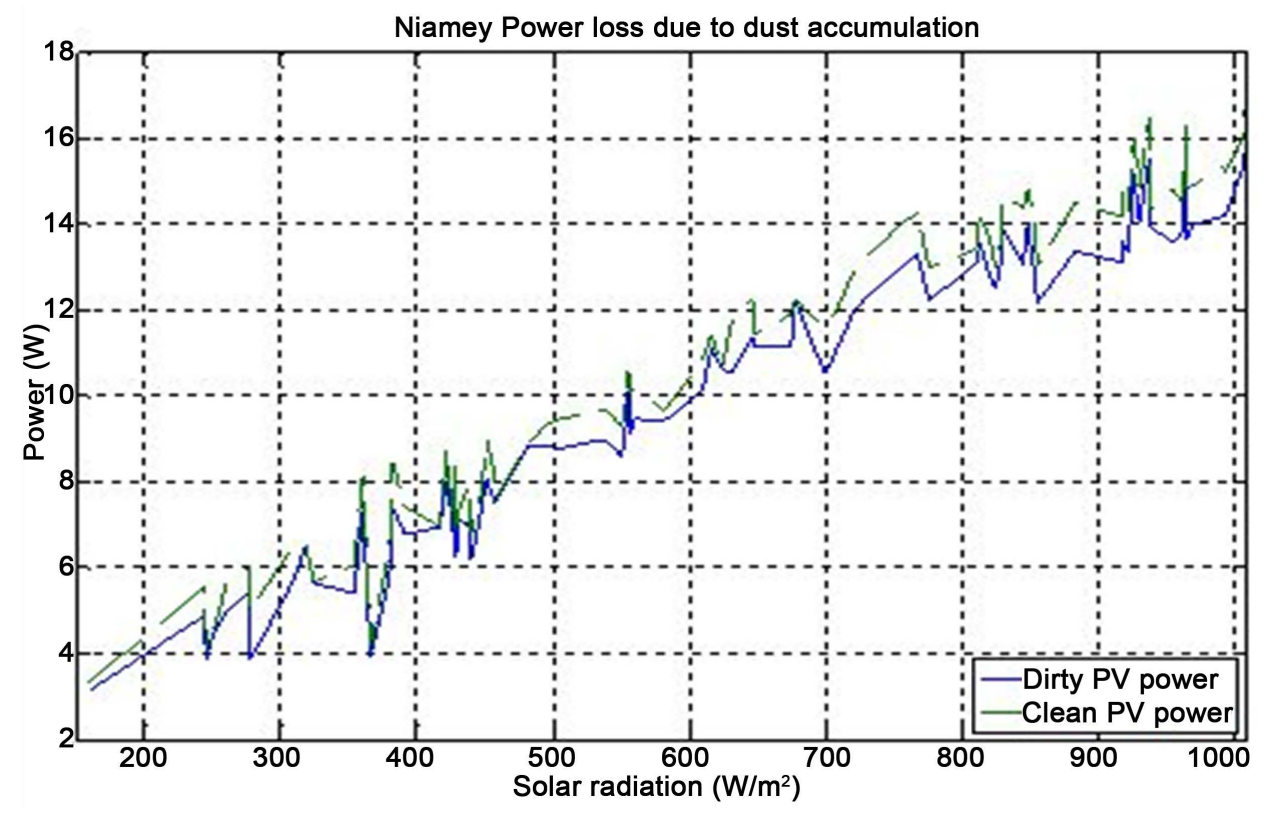

Figure 18. Power delivered by PV modules (clean and dirty) verses solar radiation in Niamey.

diance itself causes little variation in $V_{o c}$ in a non-linear manner and large variation in $I_{s c}$ linearly. Referring to the equation of the efficiency, and knowing that humidity degrades $I_{s c}$ but has insignificant effect on $V_{o c}$ the humidity global effect provokes the PV efficiency drops [40]. A case study in Nigeria tropical climate has similar result [41].

\subsection{Experiment D: Sensitivity of PV Efficiency to Dust Accumulation}

Table 5 is derived from Table 4; it summarizes the PV power loss due to dust accumulation after twenty days. The measures were conducted, the day after, on 23 September 2015). 
Table 5. Records dust effects after twenty days without cleaning (dirty PV) and daily cleaned module (Clean PV), measurements date: 23 Sept. 2015.

\begin{tabular}{ccccc}
\hline Hour & $\begin{array}{c}\text { Solar radiation } \\
\left(\mathrm{W} / \mathrm{m}^{2}\right)\end{array}$ & $\begin{array}{c}\text { Dirty PV power } \\
\mathrm{P}_{1}(\mathrm{~W})\end{array}$ & $\begin{array}{c}\text { Clean PV power } \\
\mathrm{P}_{2}(\mathrm{~W})\end{array}$ & $\begin{array}{c}\text { Relative difference } \\
\left(\mathrm{P}_{2}-\mathrm{P}_{1} / \mathrm{P}_{2}\right)(\%)\end{array}$ \\
\hline $9 \mathrm{~h} 50$ & 722 & 12.05 & 13 & 7.33 \\
$13 \mathrm{~h}$ & 966 & 13.66 & 14.8 & 7.81 \\
$15 \mathrm{~h} 05$ & 632 & 10.56 & 11.8 & 10.8 \\
$16 \mathrm{~h} 06$ & 382 & 7.4 & 8.5 & 12.46 \\
\hline
\end{tabular}

Loss due to dust accumulation is cumulative and goes up to $12.46 \%$ after 21 days of exposure. Figure 18 shows that power for both panel increases with incoming solar radiation, but the power of the clean PV module $\left(\mathrm{P}_{2}\right)$ is higher than that of the uncleaned PV module $\left(\mathrm{P}_{1}\right)$.

\section{Conclusions}

PV technologies are among the most promised renewable energy technologies and research is still ongoing to improve the efficiency in the World. PV system is rated at a standard condition different from the West African weather conditions. It is well known that efficiency of PV system is affected by local weather condition such as temperature, humidity and solar radiation but also by dust accumulation in dusty area like Sahel region. The study of the meteorological parameters impacts on the efficiency of PV in two different climate conditions (Niamey, dry climate condition and Abidjan, wet climate condition) has allow us to see that high ambient temperature (above $30^{\circ} \mathrm{C}$ ) in sahelian region decreases PV efficiency; consequently, cooling a PV system naturally or artificially, yield more power output. Elsewhere, the humidity increase decreases the PV efficiency. Generally, the efficiency of PV system in both study areas (Niamey and Abidjan), has shown that PV efficiency is much better in Abidjan than in Niamey for the same value of solar radiation. As far as climate change is concerned, temperature increases in the future will negatively impact the PV efficiency. Furthermore, this study has shown that dust accumulation in a Sahel region can induce up to $12.46 \%$ of power loss after 21 days.

In perspective, this study should be conducted on a long duration and on large space in order to really appreciate the variation of PV efficiency system according to the climatic zone and in each climatic zone according to the month and to the season. We recommend for Niamey that a maintenance should be done every two weeks due to the continuous presence of dust in such and area.

\section{Acknowledgements}

This paper is dedicated to the memory of Prof. Abdoulaye Alassanefirst Director of WASCAL Master Research Program on Climate Change and Energy (University Abdou Moumouni, Niamey, Niger). This work is a contribution of the West African Science Service Center in Climate Change and Adapted Land Uses (WASCAL)-MRP Climate 
Change and Energy (University Abdou Moumouni, Niamey, Niger). We acknowledge with thanks the scholarship and financial support provided by BMBF, The Federal Ministry of Education and Research of Germany and the West African Science Service Centre on Climate Change and Adapted Land Uses (WASCAL).

\section{References}

[1] Archer, C.L. and Jacobson, M.Z. (2005) Evaluation of Global Wind Power. Journal Geophysical. Research, 110, Article ID: D12110. http://dx.doi.org/10.1029/2004jd005462

[2] Mohamed, A.E. and. Zhengming, Z. (2013) MPPT Techniques for Photovoltaic Applications. Renewable and Sustainable Energy Reviews, 25, 793-813. http://dx.doi.org/10.1016/j.rser.2013.05.022

[3] Mahmoud, M. and Ismail, N. (1990) Analytical and Graphical Methods for Determination of Solar Cell Parameters and Investigations of Shadowing Effect. International Journal of Solar Energy, 9, 179-192. http://dx.doi.org/10.1080/01425919008941484

[4] Archer, C.L. and Jacobson, M.Z. (2012) Saturation Wind Power Potential and Its Implications for Wind Energy. Proceeding of the National Academic Sciences, 109, 15679-15684. http://dx.doi.org/10.1073/pnas.1208993109

[5] CNES (2015) Inventaire National des Installations à Energies Renouvelables, INIER-2014. Unpublished Study.

[6] RECIPES (Renewable Energy in Emerging and Developing Countries) (2006) Country Report Niger, Specific Support Action. Brussels, 1-32.

[7] Koua, B.K., Magloire, P., Kof, E., Gbaha, P. and Touré, S. (2015) Present Status and Overview of Potential of Renewable Energy in Cote d' Ivoire. Renewable and Sustainable Energy Reviews, 41, 907-914. http://dx.doi.org/10.1016/j.rser.2014.09.010

[8] Buresch, M. (1983) Photovoltaic Energy Systems Design and Installation. McGraw-Hill, New York.

[9] Marwan, M.M. (2006) Transient Analysis of a PV Power Generator Charging a Capacitor for Measurement of the I-V Characteristics. Renewable Energy, 31, 2198-2206. http://dx.doi.org/10.1016/j.renene.2005.09.019

[10] Walker, G.R. (2001) Evaluating MPPT Topologies Using a Matlab PV Model. Journal of Electrical \& Electronics Engineering, 21, 49-56.

[11] Pryor, T.L. and Carr, A.J. (2004) A Comparison of the Performance of Different PV Module Types in Temperate Climates. Solar Energy, 76, 285-294.

http://dx.doi.org/10.1016/j.solener.2003.07.026

[12] Bashir, M.A., Ali, H.M., Ali, M. and Siddiqui, A.M. (2013) An Experimental Investigation of Performance of Photovoltaic Modules in Pakistan. Thermal Science, 19, 134.

[13] Amin, N., Lung, C.W. and Sopian, K. (2009) A Practical Field Study of Various Solar Cells on Their Performance in Malaysia. Renewable and Sustainable Energy Reviews, 34, 19391946. http://dx.doi.org/10.1016/j.renene.2008.12.005

[14] Fuentes, M., Nofuentes, G., Aguilera, J., Talaverda, D.L. and Castro, M. (2007) Application and Validation of Algebraic Methods to Predict the Behavior of Crystalline Silicon PV Modules in Mediterranean Climates. Solar Energy, 81, 1396-1408. http://dx.doi.org/10.1016/j.solener.2006.12.008

[15] Pantic, S.L., Pavlovic, M.T. and Milosavljevic, D.D. (2013) A Pratical Field Study of Performances of Solar. University of Nis, Faculty of Sciences and Mathematics, Department of Physics, Republic of Serbia, 16. 
[16] Jakhrani, A.Q., Othman, A.K. and Samo, S.R. (2011) Comparison of Solar Photovoltaic Module Temperature Models. World Applied Sciences Journal, 14, 1-8.

[17] Perraki, V. and Tsolkas, G. (2013) Temperature Dependence on the Photovoltaic Properties of Selected Thin-Film Modules. International Journal of Renewable and Sustainable Energy, 4, 140-146. http://dx.doi.org/10.11648/j.ijrse.20130204.12

[18] Kurtz, S., Miller, D., Kempe, M., Bosco, M.N., Whitefield, J.K., Dhere, N. and Zgonena, T. (2009) Evaluation of High-Temperature Exposure of Photovoltaic Modules. 34th IEEE Photovoltaic Specialists Conference, Philadelphia, 7-12 June 2009, 1-9.

[19] Tanagnostopoulo, Y. and Themelis, P. (2010) Natural Flow Air Cooled Photovoltaics. AIP Conference Proceedings, 1203, 1013-1018. http://dx.doi.org/10.1063/1.3322300

[20] Garcrá, M.C.A. and. Balenzategui, J.L. (2004) Estimation of Photovoltaic Module Yearly Temperature and Performance Based on Nominal Operation Cell Temperature Calculations. Renewable Energy, 29, 1997-2010. http://dx.doi.org/10.1016/j.renene.2004.03.010

[21] Diaf, S., Notton, G., Belhamel, M. and Haddadi, M.L.A. (2008) Design and Techno-Economical Optimization for Hybrid PV/Wind System under Various Meteorological Conditions. Applied Energy, 85, 968-987. http://dx.doi.org/10.1016/j.apenergy.2008.02.012

[22] Mani, M. and Pillai, R. (2010) Impact of Dust on Photovoltaic (PV) Performance: Research Status, Challenges and Recommendations. Renewable and Sustainable Energy Reviews, 14, 3124-3131. http://dx.doi.org/10.1016/j.rser.2010.07.065

[23] Mekhilef, S., Saidur, R. and Kamalisarvestani, M. (2012) Effect of Dust, Humidity and Air Velocity on Efficiency of Photovoltaic Cells. Renewable and Sustainable Energy Reviews, 16, 2920-2925. http://dx.doi.org/10.1016/j.rser.2012.02.012

[24] Kaldellis, J.K. and Kapsali, M. (2011) Simulating the Dust Effect on the Energy Performance of Photovoltaic Generators Based on Experimental Measurements. Energy, 36, 5154-5161. http://dx.doi.org/10.1016/j.energy.2011.06.018

[25] Hottel, H. and Woertz, B. (1942) Performance of Flat Plate Solar Heat Collectors. Transactions of the American Society of Mechanical Engineers, 64, 91-104.

[26] Nimmo, B.A. and SAM, S. (1979) Effects of Dust on the Performance of Thermal and Photovoltaic Flat Plate Collectors in Saudi Arabia-Preliminary Results. Proceedings of the 2nd Miami International Conference on Alternative Energy Sources, Miami Beach, 10-12 December 1979, 223-225.

[27] Sayigh, A.A.M., Al-Jandal, S. and Ahmed, H. (1985) Dust Effect on Solar Flat Surfaces Devices in Kuwait. Proceedings of the Workshop on the Physics of Non-Conventional Energy Sources and Materials Science for Energy, Trieste, 2-20 September 1985, 353-367.

[28] Ghoneim, A.Y.A. and Al-Hasan, A. (2005) A New Correlation between Photovoltaic Panel's Efficiency and Amount of Sand Dust Accumulated on Their Surface. International Journal of Sustainable Energy, 24, 187-197. http://dx.doi.org/10.1080/14786450500291834

[29] Monocrystalline Photovoltaic Euro solar OSP-15 W Made in Eusolar Co., Ltd.

[30] Polycrystalline Photovoltaic Sunshine AP-PM 15 Made in Germany, Ref No. 01515010420 029500045.

[31] Hasan, M.A. and Sumathy, K. (2010) Photovoltaic Thermal Module Concepts and Their Performance Analysis-A Review. Renewable and Sustainable Energy Reviews, 14, 18451859. http://dx.doi.org/10.1016/j.rser.2010.03.011

[32] King, D., Ratochvil, J.A. and Boyson, W.E. (1997) Measuring the Solar Spectral and Angle of Incidence Effects on Photovoltaic Modules and Solar Irradiance Sensors. Proceedings of the 26th IEEE Photovoltaic Specialists Conference, Anaheim, 29 September-3 October 1997, 1113-1116. http://dx.doi.org/10.1109/pvsc.1997.654283 
[33] Makrides, G., Zinsser, B., Norton, M. and Georghiou, G.E. (2010) Performance of Photovoltaics under Actual Operating Conditions. In: Fthenakis, V., Ed., Third Generation Photovoltaics, InTech, 201-232. http://www.intechopen.com

[34] Bhattacharya, T., Chakraborty, A.K. and Pal, K. (2015) Statistical Analysis of the Performance of Solar Photovoltaic Module with the Influence of Different Meteorological Parameters in Tripura, India. International Journal of Engineering Research, 4, 137-140. http://dx.doi.org/10.17950/ijer/v4s3/312

[35] Tiwari, G.N. (2002) Solar Energy, Fundamentals, Design, Modelling and Applications. Narosa Publishing House, New Delhi, 525.

[36] Ugwuoke, P.E. and Okeke, C.E. (2012) Performance Assessment of Three Different PV Modules as a Function of Solar Insolation in South Eastern Nigeria. International Journal of Applied Science and Technology, 2, 319-327.

[37] Lasnier, F. and Ang, T.G. (1990) Photovoltaic Engineering Handbook. 3rd Edition, CRC Press, Boca Raton.

[38] Touati, F., Massoud, A., Hamad, J.A. and Saeed, S.A. (2013) Effects of Environmental and Climatic Conditions on PV Efficiency in Qatar. International Conference on Renewable Energies and Power Quality (ICREPQ), Bilbao, 20-22 March 2013, 1-6.

[39] Kazem, H.A., Chaichan, M.T., Al-Shezawi, I.M., Al-Saidi, H.S., Al-Rubkhi, H.S., Al-Sinani, K. and Al-Waeli, A.H.A. (2012) Effect of Humidity on the PV Performance in Oman. Asian Transactions on Engineering, 2, 29-32.

[40] Gwandu, B. and Creasey, D.J. (1995) Humidity: A Factor in the Appropriate Positioning of a Photovoltaic Power Station. Renewable Energy, 6, 313-316.

http://dx.doi.org/10.1016/0960-1481(95)00073-S

[41] Omubo-Pepple, V.B., Tamunobereton-Ari, I. and Briggs-Kamara, M.A. (2013) Influence of Meteorological Parameters on the Efficiency of Photovoltaic Module in Some Cities in the Niger Delta of Nigeria. Asian Scientific Research, 3, 107-113.

[42] Rodrigues, E.M.G., Melício, R., Mendes, V.M.F. and Catalão, J.P.S. (2011) Simulation of a Solar Cell considering Single-Diode Equivalent Circuit Model. International Conference on Renewable Energies and Power Quality, Spain, 13-15. http://www.icrepq.com/icrepq'11/339-rodrigues.pdf

\section{Submit or recommend next manuscript to SCIRP and we will provide best service for you:}

Accepting pre-submission inquiries through Email, Facebook, LinkedIn, Twitter, etc.

A wide selection of journals (inclusive of 9 subjects, more than 200 journals)

Providing 24-hour high-quality service

User-friendly online submission system

Fair and swift peer-review system

Efficient typesetting and proofreading procedure

Display of the result of downloads and visits, as well as the number of cited articles

Maximum dissemination of your research work

Submit your manuscript at: http://papersubmission.scirp.org/

Or contact cweee@scirp.org 